A streptococcal surgical wound infection traced to an anal carrier. J Pediatr 1977;90:387-90.

2 Schaffner W, Lefkowitz LB, Goodman JS, Kovick MG. Hospital outbreak of infections with group A streptococci traced to an asymptomatic carrier. $N$ Engl J Med 1969;280:1224-5.

${ }^{3}$ Ginsburg CM. Group A streptococcal vaginitis in children. Pediatr Infect Dis 1982;1:36-7.

${ }^{4}$ Amren DP, Anderson AS, Wannamaker LW. Perianal cellulitis associated with group A streptococci. Am J Dis Child 1966;112:546-52.

Correspondence to Dr G Farmer, Whittington Hospital, Highgate Hill, London N19.

Received 4 June 1987

\title{
Muscle carnitine deficiency presenting as familial fatal cardiomyopathy
}

\section{A A COLIN, ${ }^{*}$ M JAFFE, ${ }^{*}$ Y SHAPIRA $\dagger$ Z NE’EMAN $\ddagger$ A GUTMAN, $§$ AND S KORMAN*}

${ }^{*}$ Department of Paediatrics, Haifa City Medical Centre (Rothschild) and Faculty of Medicine, TechnionIsrael Institute of Technology, Haifa, and Departments of †Paediatrics, $¥$ Pathology, and §Biochemistry, Hadassah University Hospital, Jerusalem, Israel

SUMMARY Three siblings presented with fatal cardiomyopathy confirmed by electron microscopy, and normal serum but low muscle carnitine concentrations. A fourth had similar signs but remained asymptomatic. He was treated with carnitine orally which increased the concentration in muscle, though it remained below normal. Electron microscopic features were unchanged.

Carnitine deficiency was first described by Engel and Angelini in $1973 .{ }^{1}$ Carnitine is a carrier in the long chain fatty acid transport system that is essential for the transport of fatty acids across the inner mitochondrial membrane. Deficiency of carnitine affects mitochondrial oxidation of fatty acids

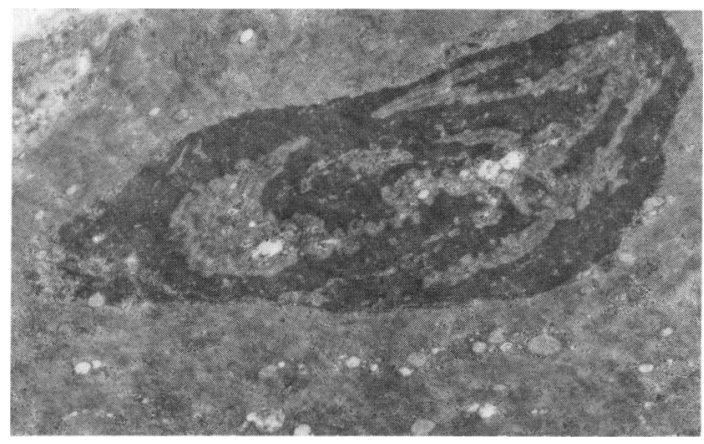

Fig 1 Electronphotomicrograph of muscle biopsy specimen from case 3 showing a myofibre with central nucleus $(\times 16500)$.

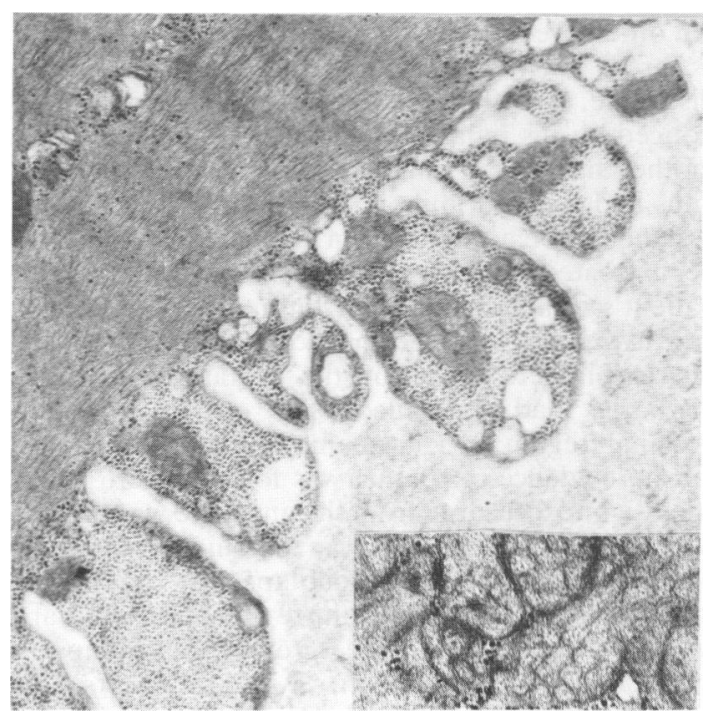

Fig 2 Electronphotomicrograph of muscle biopsy specimen from case 4 showing irregular folds of sarcolemma. Note presence of small lipid droplets under the sarcolemma and between the myofibrils $(\times 22100)$. Inset: cluster of mitochondria with tubular cristae $(\times 32500)$.

and results in the accumulation of lipids in the cytoplasm. ${ }^{2}$

We describe a non-consanguinous Sephardic family with two healthy children and three children who presented with fatal cardiomyopathy probably due to muscle carnitine deficiency (fig 1). A sixth and youngest surviving sibling was asymptomatic at 
Table Clinical and laboratory details of the siblings

\begin{tabular}{|c|c|c|c|c|}
\hline Variable & Case 1 & Case 2 & Case 3 & Case 4 \\
\hline Sex & Malc & Male & Female & Male \\
\hline Age at presentation & 3 years & 2 years 4 months & 1 year 6 months & 10 months \\
\hline Presenting illness & Wheezing & Wheezing & Wheezing & Wheezing \\
\hline Age at death & 4 years & 3 years 2 months & 3 years & Alive \\
\hline Cardiac impairment & $\begin{array}{l}\text { Right and left heart } \\
\text { failure }\end{array}$ & $\begin{array}{l}\text { Left heart failure, } \\
\text { arrhythmia }\end{array}$ & $\begin{array}{l}\text { Right and left heart } \\
\text { failure }\end{array}$ & None \\
\hline Electrocardiogram & $\begin{array}{l}\text { Left axis deviation, left } \\
\text { ventricular } \\
\text { hypertrophy, } Q \text { waves } \\
\text { in } V_{5-6}\end{array}$ & $\begin{array}{l}\text { Ventricular premature } \\
\text { beats, right bundle } \\
\text { branch block, } \mathrm{Q} \\
\text { waves in } \mathrm{V}_{5-6}, \mathrm{ST} \\
\text { elevation in } \mathrm{V}_{4-5}\end{array}$ & $\begin{array}{l}\text { Left and right } \\
\text { ventricular } \\
\text { hypertrophy, } Q \text { waves } \\
\text { and ST elevation in I, } \\
\text { AVL, } V_{5-6}\end{array}$ & Normal \\
\hline Echocardiogram & Not done & $\begin{array}{l}\text { Dilatation and } \\
\text { hypcrtrophy of left } \\
\text { atrium and ventricle, } \\
\text { ejection fraction } 0.55\end{array}$ & $\begin{array}{l}\text { Biventricular } \\
\text { hypertrophy, } \\
\text { decreased } \\
\text { contractility, } \\
\text { thickening of mitral } \\
\text { valve }\end{array}$ & Normal \\
\hline Cardiac catheterisation & Not done & $\begin{array}{l}\text { Cardiomyopathy and } \\
\text { mitral insufficiency }\end{array}$ & $\begin{array}{l}\text { No anatomic } \\
\text { abnormality, } \\
\text { decreased cardiac } \\
\text { output consistent with } \\
\text { cardiomyopathy }\end{array}$ & Not done \\
\hline $\begin{array}{l}\text { Serum glutamic } \\
\text { oxaloacetic } \\
\text { transaminase activity } \\
(\text { normal }=\leqslant 40 \mathrm{U})\end{array}$ & $\leqslant 830$ & Not done & $\leqslant 1100$ & Normal \\
\hline $\begin{array}{l}\text { Creatine } \\
\text { phosphokinase } \\
(\text { normal }=\leqslant 30 u)\end{array}$ & Not done & Not done & 34 & Normal \\
\hline $\begin{array}{l}\text { Muscle carnitine } \\
\text { (micromole/g wet } \\
\text { weight) (normal: } \\
\text { above } 1 \cdot 5 \text { ) }\end{array}$ & Not done & Not done & $0 \cdot 4$ & $0 \cdot 33$ \\
\hline $\begin{array}{l}\text { Muscle biopsy: } \\
\text { haematoxylin and } \\
\text { eosin stain }\end{array}$ & Not done & Not done & $\begin{array}{l}\text { Variation in fibre size, } \\
\text { increased number of } \\
\text { central nuclei, some } \\
\text { fibres undergoing } \\
\text { phagocytosis }\end{array}$ & Variations in fibre size \\
\hline $\begin{array}{l}\text { NADH and myosin } \\
\text { stains adenosine } \\
\text { triphosphatase }\end{array}$ & Not done & Not done & $\begin{array}{l}\text { Preponderance of type } 1 \\
\text { myofibrils and } \\
\text { atrophy of type } 2 \\
\text { fibres }\end{array}$ & $\begin{array}{l}\text { Preponderance of type } 1 \\
\text { fibres }\end{array}$ \\
\hline Oil red o stain & Not done & Not done & $\begin{array}{l}\text { Enhancement of lipid } \\
\text { stain }\end{array}$ & $\begin{array}{l}\text { Increased amount of } \\
\text { neutral lipids }\end{array}$ \\
\hline Electron microscopy & Not done & Not done & $\begin{array}{l}\text { Increased number of } \\
\text { myofibres with central } \\
\text { nuclei, lipid droplets, } \\
\text { sarcolemmal folds }\end{array}$ & $\begin{array}{l}\text { Irregular folds of the } \\
\text { sarcolemma, small } \\
\text { lipid droplets, tubular } \\
\text { cristac in } \\
\text { mitochondria }\end{array}$ \\
\hline
\end{tabular}


the time of writing but has muscle carnitine deficiency. No clinical muscle weakness was detected in any of the cases.

\section{Case reports}

The table shows the clinical and laboratory details of the four patients. Cases 1-3 died, and case 4 remained asymptomatic. When his muscle carnitine deficiency was diagnosed treatment with oral carnitine (400 $\mathrm{mg}$ three times a day) was started. Repeated examination after an interval of four months showed a rise in serum carnitine concentration to $91 \cdot 2 \mathrm{nmol} / \mathrm{ml}$. Muscle carnitine concentration was $0.9 \mu \mathrm{mol} / \mathrm{g}$ wet weight which, though still below normal, was nevertheless more than double the value before treatment. Histological and electron microscopic examination of the second muscle biopsy specimen were unchanged (fig 2). There was no clinical or laboratory evidence of muscle, heart, or liver disease.

\section{Discussion}

There are two forms of primary genetic carnitine deficiency: systemic carnitine deficiency is characterised by low concentrations of carnitine in both serum and muscle, and muscle carnitine deficiency by low concentrations in muscle but normal concentrations in serum. ${ }^{2}$ Serum carnitine deficiency presents most commonly as a syndrome similar to Reye's disease, ${ }^{2} 3$ but a familial cardiomyopathy has also been described in which carnitine treatment leads to increased serum and muscle carnitine concentrations and improved cardiac function. ${ }^{45}$

Muscle carnitine deficiency usually presents with progressive muscle weakness and is often complicated by cardiomyopathy. Because decreased transport of carnitine into the muscle cell is the pathophysiological defect treatment with oral carnitine is not usually effective. ${ }^{2}$ We know of one case report, however, in which a successful clinical response to carnitine was described. ${ }^{6}$ Muscle carnitine deficiency presenting as cardiomyopathy without noticeable muscular weakness has not previously been described as far as we know, although respiratory symptoms in children with carnitine deficiency and cardiomyopathy are common. ${ }^{45}$

Case 4 had a low muscle carnitine concentration but no clinical evidence of muscle or cardiac disease. This may be due to his being in the preclinical stage of the disease, but heterozygosity as the cause of the benign course cannot be excluded. Another possibility is that he was responding to treatment as the muscle carnitine content increased. The histopathological picture, however, did not improve over four months.

The possibility of congestive cardiomyopathy being the only sign of muscle carnitine deficiency makes estimation of muscle carnitine concentration desirable in all cases of undiagnosed cardiomyopathy. Biochemical studies of muscle specimens obtained by needle biopsy are currently widely used and relatively easy to perform.

\section{References}

1 Engel AG, Angelini C. Carnitine deficiency of human skeletal muscle with associated lipid storage myopathy: a new syndrome. Science 1973;179:899-902.

2 Rebouche CJ, Engel AG. Carnitine metabolism and deficiency syndromes. Mayo Clin Proc 1983;58:533-40.

${ }^{3}$ Chapoy PR, Angelini C, Brown WJ, Stiff JE, Shug AL, Cederbaum SD. Systemic carnitine deficiency-a treatable inherited lipid storage disease presenting as Reye's syndrome. N Engl J Med 1980;303:1389-94.

4 Tripp ME, Katcher ML, Peters HA, et al. Systemic carnitine deficiency presenting as familial endocardial fibroelastosis. N Engl J Med 1981;305:385-90.

5 Waber LJ, Valle D, Neill C, DiMauro S, Shug A. Carnitine deficiency presenting as familial cardiomyopathy: a treatable defect in carnitine transport. $J$ Pediatr 1982;101:700-5.

6 Prockop LD, King Engel W, Shug AL. Nearly fatal muscle carnitine deficiency with full recovery after replacement therapy. Neurology 1983;33:1629-31.

Correspondence to Dr AA Colin, Department of Paediatrics, Haifa City Medical Centre, PO Box 4940, Haifa 31048, Israel.

Received 11 May 1987 